Review

\title{
Escherichia coli in Europe: An Overview
}

\section{Nerino Allocati $^{1{ }^{*},}$, Michele Masulli ${ }^{1}$, Mikhail F. Alexeyev ${ }^{2}$ and Carmine Di Ilio ${ }^{1}$}

1 Department of Experimental and Clinical Sciences, "G. d'Annunzio" University of Chieti-Pescara, Chieti I-66013, Italy; E-Mails: masulli@unich.it (M.M.); carmine.diilio@unich.it (C.D.I.)

2 Department of Cell Biology and Neuroscience, University of South Alabama, Mobile, AL 36688, USA; E-Mail: malexeye@southalabama.edu

* Author to whom correspondence should be addressed; E-Mail: allocati@unich.it; Tel.: +39-0871-355-4807; Fax: +39-0871-355-4808.

Received: 15 September 2013; in revised form: 4 November 2013 / Accepted: 7 November 2013 / Published: 25 November 2013

\begin{abstract}
Escherichia coli remains one of the most frequent causes of several common bacterial infections in humans and animals. E. coli is the prominent cause of enteritis, urinary tract infection, septicaemia and other clinical infections, such as neonatal meningitis. E. coli is also prominently associated with diarrhoea in pet and farm animals. The therapeutic treatment of $E$. coli infections is threatened by the emergence of antimicrobial resistance. The prevalence of multidrug-resistant $E$. coli strains is increasing worldwide principally due to the spread of mobile genetic elements, such as plasmids. The rise of multidrug-resistant strains of E. coli also occurs in Europe. Therefore, the spread of resistance in E. coli is an increasing public health concern in European countries. This paper summarizes the current status of $E$. coli strains clinically relevant in European countries. Furthermore, therapeutic interventions and strategies to prevent and control infections are presented and discussed. The article also provides an overview of the current knowledge concerning promising alternative therapies against $E$. coli diseases.
\end{abstract}

Keywords: Escherichia coli; Gram-negative bacteria; pathotype; multidrug resistance; epidemiology; phage therapy; antimicrobial peptides; combination therapy 


\section{Introduction}

E. coli, a member of the bacterial family of Enterobacteriaceae, is the most prevalent commensal inhabitant of the gastrointestinal tracts of humans and warm-blooded animals, as well as one of the most important pathogens [1]. As a commensal it lives in a mutually beneficial association with hosts, and rarely causes disease. It is, however, also one of the most common human and animal pathogens as it is responsible for a broad spectrum of diseases. The peculiar characteristics of the E. coli, such as ease of handling, availability of the complete genome sequence, and its ability to grow under both aerobic and anaerobic condition, makes it an important host organism in biotechnology. E. coli is used in a wide variety of applications both in the industrial and medical area and it is the most used microorganism in the field of recombinant DNA technology [2].

Prior to the identification of specific virulence factors in pathogenic strains, E. coli was principally classified on the basis of the serologic identification of O (lipopolysaccharide, LPS) and H (flagellar) antigens [1]. Based on the type of virulence factor present and host clinical symptoms, E. coli strains are classified into pathogenic types (pathotypes are defined as a group of strains of the same species causing a common disease): at least seven major pathotypes for enteric E. coli, whereas three E. coli pathotypes are extraintestinal strains (ExPEC) (Table 1) [1]. Intestinal pathogens spread through the faecal-oral route by ingestion of contaminated food or water.

EPEC strains cause diarrhoea primarily in children, particularly under conditions of poor hygiene, as well as in animals [1]. EHEC is a typically food-born pathogen causing haemorrhagic colitis or HUS [1]. Typical EHEC strains produce Shiga-like toxins (named Shiga toxin producing E. coli, STEC) similar to those produced by Shigella dysenteriae making them the most virulent diarrhoeagenic E. coli known to date [3]. ETEC are the most common pathogens causing travellers' diarrhoea with mild to severe watery diarrhoea in humans of all ages [4,5]. EAEC strains are associated with persistent diarrhoea in humans, and have been recognized as the cause of several outbreaks of diarrhoeal disease worldwide. EAEC, frequently found in the gut of asymptomatic humans, is the second foremost cause of travellers' diarrhoea worldwide. EAEC is frequently associated with diarrhoea in children in developing countries and in HIV-infected patients [6,7]. DAEC causes diarrhoea particularly in children [8]. EIEC is frequently cause of watery diarrhoea and occasionally dysentery in both children and adults [1]. EIEC strains are closely related to Shigella spp. AIEC is a recently emerged pathotype which has been associated with Crohn's disease lesions $[9,10]$.

ExPEC are frequently associated with nosocomial and community-associated infections. UPEC, distinct from the commensal E. coli strains in the phenotypic tracts and in virulence factors, is the most common microorganism of urinary tract infections (UTIs) in humans and is responsible for approximately $80 \%$ of the cases $[1,11]$. NMEC is a major cause of Gram-negative neonatal bacterial meningitis in developed countries with neurologic sequelae in many of the survivors [12]. In the last years, a significant increase in multidrug resistant NMEC strains has been observed [13]. APEC, an additional animal pathotype found in the intestinal microflora of healthy birds, is responsible for extraintestinal diseases in several avian species [14,15]. Recent studies have revealed that APEC and ExPEC have similarities in their serogroups and virulence factors suggesting a possible source of food-borne diseases [14,15]. Hovewer, the capacity of APEC to cause illness in human has not yet been verified [16]. 
Table 1. E. coli pathogenic types.

\begin{tabular}{|c|c|c|c|c|}
\hline Pathotype (acronym) & Diseases & Symptoms & Virulence factors & Ref. \\
\hline \multicolumn{5}{|l|}{ Enteric E.coli } \\
\hline EnteroPathogenic E. coli (EPEC) & $\begin{array}{l}\text { Diarrhoea in } \\
\text { children }\end{array}$ & $\begin{array}{l}\text { Watery diarrhoea } \\
\text { and vomiting }\end{array}$ & Bfp, Intimin, LEE & {$[1]$} \\
\hline EnteroHaemorrhagic E. coli (EHEC) & $\begin{array}{l}\text { Haemorrhagic } \\
\text { colitis, HUS }\end{array}$ & Bloody diarrhoea & $\begin{array}{l}\text { Shiga toxins, } \\
\text { Intimin, Bfp }\end{array}$ & {$[1,3]$} \\
\hline EnteroToxigenic E. coli (ETEC) & $\begin{array}{l}\text { Traveler's } \\
\text { diarrhoea }\end{array}$ & $\begin{array}{l}\text { Watery diarrhoea } \\
\text { and vomiting }\end{array}$ & $\begin{array}{l}\text { Heat-labile } \\
\text { and sheat-stable } \\
\text { toxins, CFAs }\end{array}$ & {$[4,5]$} \\
\hline EnteroAggregative E. coli (EAEC) & $\begin{array}{l}\text { Diarrhoea in } \\
\text { children }\end{array}$ & $\begin{array}{l}\text { Diarrhoea with } \\
\text { mucus and } \\
\text { vomiting }\end{array}$ & AAFs, cytotoxins & {$[6,7]$} \\
\hline Diffusely Adherent E. coli (DAEC) & $\begin{array}{l}\text { Acute diarrhoea } \\
\text { in children }\end{array}$ & $\begin{array}{l}\text { Watery } \\
\text { diarrhoea, } \\
\text { recurring UTI }\end{array}$ & Daa, AIDA & [8] \\
\hline EnteroInvasive $E$. coli (EIEC) & Shigellosis-like & $\begin{array}{l}\text { Watery } \\
\text { diarrhoea; } \\
\text { dysentery } \\
\end{array}$ & $\begin{array}{l}\text { Shiga toxin, } \\
\text { hemolysin, Cellular } \\
\text { invasion, Ipa }\end{array}$ & {$[1,7]$} \\
\hline Adherent Invasive $E$. coli (AIEC) & $\begin{array}{l}\text { Associated with } \\
\text { Crohn disease }\end{array}$ & $\begin{array}{l}\text { Persistent } \\
\text { intestinal } \\
\text { inflammation }\end{array}$ & $\begin{array}{l}\text { Type } 1 \text { fimbriae, } \\
\text { Cellular invasion }\end{array}$ & {$[9,10]$} \\
\hline \multicolumn{5}{|l|}{ Extraintestinal E. coli (ExPEC) } \\
\hline UroPathogenic E. coli (UPEC) & $\begin{array}{l}\text { Lower UTI } \\
\text { and systemic } \\
\text { infections }\end{array}$ & $\begin{array}{l}\text { Cystitis, } \\
\text { pyelonephritis }\end{array}$ & $\begin{array}{l}\text { Type } 1 \text { and } \\
\text { P fimbriae; } \\
\text { AAFs, hemolysin }\end{array}$ & {$[1,11]$} \\
\hline Neonatal Meningitis E. coli (NMEC) & $\begin{array}{l}\text { Neonatal } \\
\text { meningitis }\end{array}$ & $\begin{array}{l}\text { Acute } \\
\text { meningitis, sepsi }\end{array}$ & $\begin{array}{l}\text { S fimbrie; } \\
\text { K1 capsule }\end{array}$ & {$[12,13]$} \\
\hline Avian Pathogenic E. coli (APEC) & $\begin{array}{l}\text { Probable source } \\
\text { of food-borne } \\
\text { disease }\end{array}$ & - & $\begin{array}{l}\text { Type } 1 \text { and } \\
\text { P fimbriae; } \\
\text { K1 capsule }\end{array}$ & {$[14,15]$} \\
\hline
\end{tabular}

Bfp: Bundle-forming pili; LEE: Locus for enterocyte effacement; HUS: haemolytic-uraemic syndrome; CFA: colonization factor antigen; AAF: aggregative adherence fimbria; Daa: diffuse adhesin; AIDA: adhesin involved in diffuse adherence; Ipa: Invasion plasmid antigen.

\section{Mechanisms of Resistance}

Antimicrobial resistance is a major and increasing global healthcare problem [17]. Since the introduction of the penicillin, a large number of bacteria have responded to the use of antibiotics with their ability to evolve and transmit antimicrobial resistance to other species [18]. Increased consumption of antimicrobial agents and their inappropriate use are among factors which further accelerated this phenomenon. Furthermore, the continuous migration of people between countries as well as international tourism and business travel play an important role in the acquisition and spread of multidrug resistant strains [19].

Antimicrobial resistance was also observed in animals, where the antimicrobials are used for therapy and prophylaxis of infectious diseases [20]. As in humans, the use of antimicrobials leads to an 
increased incidence of resistance in both pathogenic and endogenous bacteria [20]. Resistant bacteria from animals can infect humans by direct contact as well as via food products of animal origin. Multidrug resistance is defined as resistance to three or more antimicrobial classes to which bacteria do not show intrinsic resistance [21]. Multi-resistant strains are on the rise worldwide principally due to the spread of genes located on mobile genetic elements, including plasmids, integrons and transposons. Furthermore, the combination of these genes with chromosomally encoded resistance genes frequently results in bacteria that are resistant to all main classes of available antimicrobials $[1,22]$.

E.coli is intrinsically resistant to therapeutic levels of penicillin $\mathrm{G}$, the first $\beta$-lactam introduced into clinical practice, because of its outer membrane barrier. E. coli is also resistant to several different classes of antibiotics with distinct mechanisms of action [23,24]. However, this paper was restricted to $\beta$-lactams, quinolones and aminoglycosides, because the invasive $E$. coli isolated in the reporting countries were mainly resistant to their action [25]. Moreover, these molecules are defined "critically important antimicrobials" for human medicine [26].

In $E$. coli, $\beta$-lactamase production is the most important mediator of resistance to broad spectrum of $\beta$-lactams. $\beta$-lactamases constitute a wide class of enzymes, which are often encoded on plasmids, and are most commonly produced by Enterobacteriaceae in general and by E. coli in particular. $\beta$-lactamases confer resistance to penicillins and cephalosporins and are an emerging cause of multidrug resistance in Gram-negative bacteria. Several different types of $\beta$-lactamases have been described (Table 2) [27]. ESBLs confer resistance to several antibiotics including third- and fourth-generation cephalosporins and monobactams. The CTX-M-1 cluster is now the most prevalent type all over the world with the CTX-M-15 being the most identified variant [27-34]. In Europe, CTX-M-14 and CTX-M-15 types are widely distributed among humans [34]. Conversely, CTX-M-1 variant is the most prevalent among animals [34].

Carbapenem resistance in Enterobacteriaceae is a new emerging problem caused primarily by plasmid-encoded carbapenemases (Table 2) [25,35-40]. To date, these enzymes are mainly found in nosocomial isolates of Klebsiella pneumoniae and E. coli [36,38]. In Europe, carbapenemases-producing isolates are differently distributed among countries [35-40]. Furthermore, the prevalence of these strains appears to follow a north-south distribution [36,40].

E. coli also exhibits (fluoro)quinolone resistance which is frequently observed in conjunction with ESBL genes. Fluoroquinolone resistance in bacteria can be conferred by both chromosomal and plasmid-encoded genes (Table 2) [41-44]. Fluoroquinolone resistance qnr and aac(6')Ib-cr genes have been frequently associated with $\beta$-lactam resistance genes, mainly $b l a_{\text {СТХ-M-14 }}$ and bla $a_{\text {CTX-M-15 }}[32,45]$.

The aminoglycosides are bactericidal antibiotics, which act to inhibit protein synthesis, binding to the aminoacyl site of $16 \mathrm{~S}$ rRNA within the bacterial $30 \mathrm{~S}$ ribosomal subunits. There are several mechanisms that can cause bacterial resistance to aminoglycoside antibiotics (Table 2) [46-49]. In the last few years, alteration of 16S rRNA site by methyltransferase enzymes has emerged as a serious threat to this antimicrobial class. Of particular concern is $16 \mathrm{~S}$ rRNA methyltransferase armA gene that confers pandrug-resistance to aminoglycosides and which is often accompanied by the carbapenemase genes on the same mobile genetic element $[25,50,51]$. 
Table 2. Mechanisms of resistance.

\begin{tabular}{|c|c|c|c|}
\hline Mechanism & Example & Target & Ref. \\
\hline \multirow{6}{*}{ Enzyme inactivation } & $\beta$-lactamases: TEM-type; SHV-type. & $\begin{array}{l}\text { Broad-spectrum } \\
\text { penicillins }\end{array}$ & {$[27]$} \\
\hline & ESBLs: & \multirow{4}{*}{$\begin{array}{l}\text { Penicillins and } \\
\text { cephalosporins }\end{array}$} & \multirow{4}{*}[27-34]{} \\
\hline & $\begin{array}{l}\text { TEM/SHV-type variants; } \\
\text { Clusters: CTX-M-1, CTX-M-2, CTX-M-8, } \\
\text { CTX-M-9, CTX-M-25; }\end{array}$ & & \\
\hline & GES/PER/VEB types (less frequently). & & \\
\hline & Class A: serine-carbapenemases; & & \\
\hline & $\begin{array}{l}\text { Class B: active zinc site metallo- } \beta \text {-lactamases; } \\
\text { Class D: OXA } \beta \text {-lactamases. }\end{array}$ & Carbapenems & {$[35-40]$} \\
\hline & Alterated target enzymes: & \multirow{3}{*}{ Quinolones } & \multirow[b]{2}{*}[41,42]{} \\
\hline Chromosomal mutations & $\begin{array}{l}\text { DNA gyrase, topoisomerase IV. } \\
\text { Decreased antimicrobial uptake: } \\
\text { decrease in membrane permeability; } \\
\text { overexpression of efflux pumps. }\end{array}$ & & \\
\hline $\begin{array}{l}\text { Plasmid-mediated } \\
\text { quinolone resistance }\end{array}$ & TMQRs: Qnr, AAC(6')-Ib-cr), QepA, OqxAB. & & {$[43,44]$} \\
\hline Enzyme inactivation & $\begin{array}{l}\text { Acetyltransferases, nucleotidyltransferases, } \\
\text { phosphotransferases. }\end{array}$ & \multirow{3}{*}{ Aminoglycosides } & \multirow{3}{*}{ [46-49] } \\
\hline $\begin{array}{l}\text { Decreased antimicrobial } \\
\text { uptake }\end{array}$ & $\begin{array}{l}\text { decrease in membrane permeability; } \\
\text { overexpression of efflux pumps. }\end{array}$ & & \\
\hline 16S rRNA methylation & ArmA/Rmt family & & \\
\hline
\end{tabular}

ESBLs: Extended spectrum $\beta$-lactamases; TMQRs: transferable mechanisms of quinolone resistance.

\section{Epidemiology of Resistance}

In Europe, antimicrobial resistance in Gram-negative bacteria is on the rise, particularly in E. coli, which constitutes a majority of invasive Gram-negative isolates in European countries [25,32,33,52-59]. The emergence and diffusion of multi-drug resistant strains of $E$. coli is complicating the treatment of several serious infections. Enterobacteriaceae, particularly E. coli, are the most frequent cause of hospital- and community-acquired infections [60-62].

Multidrug-resistant E. coli strains are also commonly isolated from animals and food products [34,63-69]. The use of antibiotics in animals contributed to the emergence and spread of the number of antibiotic-resistant strains, including $E$. coli, which can also infect humans through either direct contact with animals or through consumption of contaminated food [34]. E. coli is able to survive and adapt in various extraintestinal habitats and to spread resistances between humans, animals, their products and the environment through several transmission pathways [34].

Environment plays a key role in the spread of antimicrobial resistance serving as an unlimited reservoir of antimicrobial resistance genes [70]. Therefore, E. coli may acquire other drug resistance traits from environmental bacteria and conversely it can spread its resistance genes to potential pathogens in different habitats [71]. A source of multi-resistant E. coli could be represented by hospital effluents [72]. Several studies have reported the presence of multi-resistant strains in hospital effluents 
contributing to the spread of their antibiotic resistance genes in the municipal sewage systems and in the environment [72].

Antimicrobial resistant E. coli strains are distributed Europe-wide. The percentage of resistance to specific antibiotics in human sources varies substantially between countries - showing a north-to-south gradient - with the southern regions having the highest prevalence of resistance [25]. These geographical variations probably reflect differences in infection control practices and antibiotic use in the european countries. In Table 3 is presented the percentage $(\% \mathrm{R})$ of invasive strains, isolated from blood or cerebrospinal fluid, with resistance to three antimicrobials and with multi-resistance to all three antimicrobial classes. Data were analysed in accordance with the breakpoint criteria used by the local laboratory. The most widely used were EUCAST and CLSI breakpoints [25].

In the last annual surveillance report of the European Centre for Disease Prevention and Control (ECDC, data 2011), the presence of isolates resistant to third-generation cephalosporins, fluoroquinolones and aminoglycosides as well as isolates with resistance to all three antimicrobial classes was observed in all analyzed countries (27 EU Member States and three European Economic Area countries: Norway, Iceland and Liechtenstein) [25]. The percentage of isolates that express resistance to third-generation of cephalosporins is lowest in Sweden (3.0\%), Norway (3.6\%) and Finland (5.1\%) and highest in Bulgaria (22.9\%), Slovakia (31\%) and Cyprus (36.2\%). E. coli strains resistant to fluoroquinolones were present in low numbers in Sweden $(7.9 \%)$, Norway (9.0\%) and Estonia (9.9\%) while they were predominant in Italy (40.5\%), Slovakia (41.9\%) and Cyprus (47.4\%). Furthermore, the prevalence of isolates resistant to aminoglycosides ranged from $3.7 \%$ (Sweden) to $23.9 \%$ (Cyprus). The percentage is also higher in Romania (19.6\%) Slovakia (17.9\%) and Greece (16.8\%). Finally, the prevalence of isolates with multi-resistance ranged from about 1\% (i.e., Estonia, Iceland and Sweden) to more than $10 \%$ (i.e., Romania, Slovakia and Cyprus). Strains resistant to broad-spectrum penicillins were isolates in 28 countries, falling in the range of $34.8 \%$ (Sweden) to $77.6 \%$ (Cyprus). In contrast, only $0.04 \%$ of 59,326 isolates of $E$. coli were found to be resistant to carbapenems [25]. However, a recent survey reported that carbapenemase-producing Enterobacteriaceae continue to spread in Europe [40].

Antimicrobial resistance is also on the rise in European countries that were not included in the last annual ECDC report (Table 3) $[19,57,59,66,73,74]$. In a recent surveillance study conducted in 42 centres in Eastern Europe, about $15 \%$ of E. coli isolates were ESBL-positive and were collected in all countries participating in this project [59]. Turkey had the highest percentage with $25.2 \%$ of all ESBL-positive strains isolated [59]. Studies on fluoroquinolone resistance were also reported in Turkey [57,75]. Although prevalence of $q n r$ genes among isolates is low, these strains exhibit a high level of resistance [68]. E. coli strains resistant to various antimicrobials were also isolated in Switzerland, Croatia and Bosnia and Herzegovina [57,74]. Fluoroquinolone resistance in E. coli was prevalent in these countries. Furthermore, multiresistant strains were also isolated, except in Bosnia and Herzegovina, probably due to limited surveillance data available for these countries [57]. ESBL-positive E. coli isolates resistant to quinolones and aminoglycosides were detected in Russia $[37,45,56]$. Resistance rates to ciprofloxacin and nalidixic acid in isolates were $12.9 \%$ and $17.2 \%$ respectively. Moreover, a lower percentage was observed for ESBL-positive isolates [45]. No data were found for other European countries, despite an extensive search. 
Table 3. Antibiotic resistance of E. coli isolated (\%R) from human sources in Europe.

\begin{tabular}{|c|c|c|c|c|c|}
\hline Country & $\begin{array}{l}\text { Third-generation } \\
\text { cephalosporines }\end{array}$ & Fluoroquinolones & Aminoglycosides & $\begin{array}{l}\text { Multi- } \\
\text { resistance }\end{array}$ & Ref. \\
\hline Austria & 9.1 & 22.3 & 7.4 & 2.6 & {$[25]^{b}$} \\
\hline Belgium & 6.0 & 21.5 & 9.3 & 1.4 & {$[25]$} \\
\hline $\begin{array}{l}\text { Bosnia and } \\
\text { Herzegovina }\end{array}$ & 3.0 & 15.0 & 3.0 & 0 & {$[57]^{\mathrm{c}}$} \\
\hline Bulgaria & 22.9 & 30.2 & 17.3 & 10.1 & [25] \\
\hline Croatia & 4.0 & 15.0 & 7.0 & 1.0 & [57] \\
\hline Cyprus & 36.2 & 47.4 & 23.9 & 18.2 & {$[25]$} \\
\hline Czech Republic & 11.4 & 23.5 & 8.8 & 3.7 & {$[25]$} \\
\hline Denmark & 8.5 & 14.1 & 6.4 & 3.0 & {$[25]$} \\
\hline Estonia & 12.2 & 9.9 & 4.8 & 1.1 & {$[25]$} \\
\hline Finland & 5.1 & 10.8 & 5.3 & 2.7 & {$[25]$} \\
\hline France & 8.2 & 17.9 & 7.9 & 2.6 & [25] \\
\hline Germany & 8.0 & 23.7 & 7.6 & 3.6 & {$[25]$} \\
\hline Greece & 14.9 & 26.6 & 16.8 & 10.8 & {$[25]$} \\
\hline Hungary & 15.1 & 31.2 & 14.8 & 8.3 & {$[25]$} \\
\hline Iceland & 6.2 & 14.0 & 6.2 & 0.8 & {$[25]$} \\
\hline Ireland & 9.0 & 22.9 & 10.2 & 3.6 & {$[25]$} \\
\hline Italy & 19.8 & 40.5 & 18.3 & 10.3 & {$[25]$} \\
\hline Latvia & 15.9 & 16.8 & 11.4 & 9.2 & {$[25]$} \\
\hline Lithuania & 7.0 & 12.9 & 9.7 & 2.4 & {$[25]$} \\
\hline Luxembourg & 8.2 & 24.1 & 8.2 & 2.8 & {$[25]$} \\
\hline Malta & 12.8 & 32.0 & 15.5 & 9.6 & [25] \\
\hline Netherlands & 5.7 & 14.3 & 7.8 & 2.2 & {$[25]$} \\
\hline Norway & 3.6 & 9.0 & 4.1 & 1.2 & {$[25]$} \\
\hline Poland & 11.7 & 27.3 & 8.4 & 4.0 & {$[25]$} \\
\hline Portugal & 11.3 & 27.2 & 16.1 & 7.5 & [25] \\
\hline Romania & 22.0 & 30.4 & 19.6 & 10.9 & [25] \\
\hline Slovakia & 31.0 & 41.9 & 17.9 & 12.9 & [25] \\
\hline Slovenia & 8.8 & 20.7 & 9.8 & 4.1 & [25] \\
\hline Spain & 12.0 & 34.5 & 14.8 & 4.9 & [25] \\
\hline Sweden & 3.0 & 7.9 & 3.7 & 1.0 & [25] \\
\hline Switzerland & 3.0 & 15.0 & 7.0 & 1.0 & [57] \\
\hline Turkey & 42.0 & 52.0 & 35.0 & 23.0 & [57] \\
\hline United Kingdom & 9.6 & 17.5 & 8.2 & 3.6 & [25] \\
\hline
\end{tabular}

${ }^{\mathrm{a}}$ Isolates with resistance to all three antimicrobial classes; ${ }^{\mathrm{b}}$ data $2011 ;{ }^{\mathrm{c}}$ data 2008.

\section{E. coli Outbreaks}

The epidemiology of $E$. coli-associated infections varies widely depending on the type of strain involved. In the last years in Europe, E. coli outbreaks were mainly caused by various EHEC strains.

STEC E. coli O104:H4 has been responsible for a large number of outbreaks in the recent years $[3,76,77]$. During the spring of 2011, a novel E. coli O104:H4 serotype infected about 4,000 individuals in Central Europe, mainly in Germany, provoking more than 900 cases of HUS [54,76]. 
This particular pathogen demonstrated a combination of virulence factors from both EAEC and EHEC strains [76]. A strain similar to the current outbreak strain had been previously isolated and characterised in Republic of Georgia [76].

HUS cases were reported in several European countries (Data 2010 [54]). The prevalent serogroups identified are O157 (EHEC O157:H7 serotype is the predominant cause of HUS) and O26. The highly virulent EHEC O26: $\mathrm{H} 11 / \mathrm{H}^{-}$serotype is emerging in Europe [78].

E. coli $\mathrm{O} 25 \mathrm{~b}: \mathrm{H} 4 / \mathrm{ST} 131$ (sequence type 131) is an emerging disseminated multidrug-resistant ExPEC strain, causing a broad spectrum of diseases, mainly urinary tract infections $[31,65,79]$. E coli $\mathrm{O} 25 \mathrm{~b}: \mathrm{H} 4 / \mathrm{ST} 131$ is widely distributed in Europe, with Spain and Italy most prominently affected $[30,31,79,80]$.

\section{Prevention and Control of $E$. coli Infections}

In general, strategies for the prevention and control of the spread of E. coli should include access to safe water, good handling practices to reduce the risk of food contamination, sanitation measures, public education and vaccination [81-83].

Access to safe water is the primary target for the prevention of E. coli infections. Although this problem does not directly affect European countries, worldwide hundreds of millions people still do not have access to improved water sources (WHO/UNICEF Joint Monitoring Programme for Water Supply and Sanitation, 2012). Measures to prevent infections from food products include appropriate storage and cooking temperatures. Food irradiation technology may be used to drastically reduce bacterial load in high-risk products. Its use is authorised in European Union but limited to several products (EU Directive 1999/2/EC and 2009/C 283/02) However, food irradiation cannot be used as a substitute for hygiene and health practices or food good manufacturing or agricultural practice (EU Directive 1999/2/EC).

Hospital measures that limit risk of the spread of multiresistant pathogens include prevention of cross-contamination by implementing strict hygienic standard protocols as well as control over the use of antimicrobial drugs [81]. The main vehicles for pathogens' spread are the hands of hospital workers and medical devices. Proper hand hygiene is critical for the prevention of cross-contamination.

Antibiotics are essential for the control and treatment of $E$. coli infections in humans and animals. However, it is generally accepted that antimicrobial resistance is associated with the quantity of antibiotic consumption [52]. The inappropriate use and misuse of antimicrobials increased the resistance in pathogens as well as in normal human bacterial flora in both. Animal reservoir is also an important source for resistance strains. Furthermore, the wide spread of antimicrobial therapy also results in the environmental release of antibiotics and antibiotic resistance genes with consequent selection of resistant bacteria. The effects of environmental release of the resistance genes are poorly studied. Antibiotic pollution promotes the fixation and mobilization of resistance genes between natural and clinical environments with world-wide spreading of resistance traits [84].

For this reason, a rational and responsible use of antibiotics should be a prerequisite for the prevention of the emergence and transmission of resistant bacteria [82]. Furthermore, appropriate strategies for monitoring and surveillance of the use of antibiotics are essential for the control and containment of the resistance, for the control of changes in bacterial populations, and for the 
development of suitable therapeutic strategies. Finally, greater attention should be given to the risks associated with release of antimicrobials into environment [84].

Probiotics could be an approach to the prophylaxis of several E. coli infections [85]. Probiotics are viable and safe microorganisms, principally belonging to the genera Lactobacillus and Bifidobacterium, which are able to colonize intestinal tract and thereby compete with pathogenic bacteria. Several studies on the potential use of probiotics for the prevention or therapy of gastrointestinal infections have been conducted. Treatment of infectious diarrhoea with probiotics demonstrated beneficial effects by reducing diarrhoea rates [86]. Studies on the effects of probiotics on inflammatory bowel diseases, including Crohn's disease, also demonstrated beneficial effects, although results were modest [87]. The use of Lactobacillus, which is part of the microbiota in healthy humans, in the form of probiotics reduced the risk of UTI and vaginal infections [88].

Vaccination may be an important primary prevention strategy for human against the most harmful strains, such as ETEC, UPEC and NMEC. To date, no effective vaccine is available yet for the prevention of these infections.

Vaccine development against ETEC is still a global priority considering a high number of individuals infected both in developing countries and among travellers. Protective strategies against ETEC strains proved difficult to develop. However, several studies are in progress to obtain an effective vaccine that may have a substantial impact on children's health in developing countries as well as protect travellers when visiting ETEC endemic areas [89,90]. In some countries, a cholera vaccine was used against ETEC strains to stimulate anti-heat-labile toxin immunity for short term protection [5].

About $80 \%$ of uncomplicated UTI are caused by UPEC, and the annual economic impact of this type of illness is very high, principally due to the costs associated with medical care and loss of productivity. Moreover, patient relapse after antibiotic therapy is not uncommon. All these considerations stimulate an ongoing search for the effective UPEC vaccine [91].

On the NMEC front, researchers implemented a non-conventional approach to vaccine development, research vaccinology [92]. This is an emerging genome-based vaccine development strategy that takes advantage of the complete repertoire of possible antigens that a bacterium can encode [83]. Preliminary data demonstrate that some antigens identified in NMEC, and combined with antigens of others ExPEC, could be used to develop a widely cross-reactive vaccine against ExPEC [92].

\section{Alternative Therapies}

The worldwide emergence of multidrug-resistant bacteria has dramatically limited the number of antibiotics that retain activity against these pathogens [93]. This problem has been further amplified by the dearth of novel classes of antibiotics. Therefore, development of novel therapeutic strategies for infectious diseases is high demand. In response, several new therapies have been developed, such as phage therapy, antimicrobial peptide therapy and combinations of two or more antibiotics [94-97].

The potential use of bacteriophages as therapeutic agents was recognized from the 1900s [95,98]. However, this therapeutic approach was eclipsed by the discovery and use of antibiotics. Nevertheless, phage therapy was used for the treatment of human bacterial infections, mainly in Eastern Europe $[98,99]$. Recently, the rise of multidrug-resistant bacteria and the consequent decrease in the 
number of effective antibiotics has forced scientists to search for alternative therapies [95]. Phages have a number of advantages that make them attractive for therapeutic use against bacteria [100]. First, they are highly specific and can be very effective in lysing bacteria. Second, phages are safe as underscored by several clinical studies, and third, they can be readily modified to fight the emergence of new multiresistant bacterial strains [100]. Many studies characterizing lytic phages specific for different $E$. coli strains have been published demonstrating their potential therapeutic value [13,101-106].

For example, phages are a promising therapeutic for UTIs caused by biofilm-forming UPEC strains. The majority of the UPEC strains produce biofilms which highly increase resistance to antibiotics. It has been observed that phages are able to pass through the extracellular matrix, to degrade the biofilm and kill bacteria [104,107,108]. A potential phage therapy was also demonstrated for sepsis and meningitis caused by NMEC multidrug resistant strain [13]. In experimental meningitis caused by a NMEC strain, the phage is able to cross the blood-cerebrospinal fluid barrier sterilizing the CSF [13].

Phages are also used to support food safety $[105,109,110]$. They are employed in food industry to prevent the contamination and bacterial proliferation on products, and to reduce bacterial charge during industrial food processing [105]. Phages are studied as disinfectants to control microbial contamination on food contact surfaces and equipment. Moreover, phage therapy was attempted to treat bacterial infections in animals [111,112].

In addition to therapeutic use of lytic phages, phage-encoded enzymes can be potentially used as an effective antibacterials against pathogens. Endolysins are hydrolase enzymes produced by phages at the end of their replication cycle to digest the bacterial cell wall for the release of progeny virions [113]. Endolysins work equally well when applied exogenously to bacterial cells and thus these enzymes are potentials candidates as new antibacterial agents [113,114].

The results obtained so far paint a positive picture for the future prospects of phage therapy against E. coli infections.

Antimicrobial peptides (AMPs) are an abundant and diverse group of molecules that are produced by eukaryotic and prokaryotic organisms or encoded by phages [96,97,115]. In eukaryotes, AMPs contribute to innate immune responses and defend organisms against potentially harmful microbes [97]. Bacteria use AMPs, referred to as bacteriocins, to kill other competitors in the same ecological niche. They are typically cationic amphipathic small peptides whose main mode of action is the ability to insert into membrane bilayers to form channels resulting in cell death [115]. Phage-encoded AMPs are a group of different lytic factors that allow for the release of viral progeny into the environment [97].

Several AMPs are being developed as drugs. They are able to act against antibiotic-resistant pathogens and are less susceptible to bacterial resistance than conventional antibiotics. Synthetic AMPs have been also developed, with designs based on common structural elements in natural peptides [96,116]. Synthetic AMPs are much more active than their native counterparts, less sensitive to proteases and have a low host toxicity profile.

Numerous natural and synthetic AMPs have direct activity against wide range of microorganisms including Gram-positive and Gram-negative. There are also several reports in the literature regarding activity of AMPs against E. coli strains [117-120]. Taken together, the results obtained so far highlight that AMPs represent a new promising therapeutic option for the treatment of bacterial diseases, including infections due to multidrug-resistant strains. 
A novel approach to combating infections caused by multidrug resistant bacteria is combination therapy. The use of two or more antimicrobial agents simultaneously is a common practice for the treatment of several infectious, such as malaria, HIV and tuberculosis [94]. The use of combination therapy for the treatment of multidrug resistant bacteria, especially Gram-negative, could be an alternative to the development of new antibacterial drugs [121]. However, there is still considerable debate over the role of combination therapy versus monotherapy for Gram-negative infections. Although there are numerous reasons why combination therapy may be superior to monotherapy, the results obtained in clinical studies are not conclusive [121,122]. It has been suggested that combination therapy for the empirical treatment of severe Gram-negative infections, to be followed by transition to monotherapy once susceptibilities have been determined [122].

An alternative therapeutic strategy against multi-resistant bacteria could be the use of efflux pump inhibitors [123]. Efflux is a well known antibiotic resistance mechanism, bacteria being capable to export actively molecules from the cell using efflux pumps [124]. Although not used in the clinical practice yet, the high therapeutic potential of the combination of efflux pumps inhibitors with antibiotics has been clearly demonstrated [123]. Furthermore, this co-therapy would allow for the use of antibiotics normally compromised by efflux pump activity.

\section{E. coli as a Biological Weapon}

E. coli is present in the Centers for Disease Control and Prevention (CDC) list of biological agents potentially threat to public health and safety [125]. Several microorganisms or their products can be used as biological weapon for warfare and bioterrorism. The CDC classifies potential agents as biological weapon in three categories. In Category A agents which can be easily disseminated or spread from person to person, resulting in high mortality rate and impact on public health are listed. Category $\mathrm{B}$ lists pathogens moderately easy to disseminate, resulting in moderate morbidity rates and low mortality rates. Category $\mathrm{C}$ lists emerging pathogens with potentially high morbidity and mortality and which can be engineered for mass dissemination. E. coli $\mathrm{O} 157: \mathrm{H} 7$ strain is present in Category B as "food safety threat". Even though less dangerous than Category A agents, Category B agents are easier to produce and handle, and the use of such agents against civilian populations by terrorists might well cause considerable panic [126].

\section{Conclusions}

Antimicrobial resistance in Europe continues to increase, markedly in Gram-negative bacteria, with considerable fluctuation between countries. In both humans and animals, the use of antimicrobials caused an increase in the incidence of resistance in both pathogenic and endogenous bacteria, highlighting a serious health problem to human medicine.

Information obtained from systematic surveillance studies is essential for monitoring changes in the antimicrobial resistance among pathogens, and for appropriate antibiotic treatments [127]. Therefore, to improve and enforce this network surveillance studies should be extended to all European countries. For this purpose, Central Asian and eastern European Surveillance on Antimicrobial Resistance (CAESAR) network has been established with the aim to expand surveillance to all european countries that are not part of the European Antimicrobial Resistance Surveillance Network (EARS-Net). 


\section{Acknowledgments}

This work was partially supported by the Italian "Ministero per l'Istruzione, l'Università e la Ricerca" (MIUR).

\section{Conflicts of Interest}

The authors declare no conflict of interest.

\section{References}

1. Kaper, J.B.; Nataro, J.P.; Mobley, H.L. Pathogenic Escherichia coli. Nat. Rev. Microbiol. 2004, 2, 123-140.

2. Yoo, S.H.; Jeong, H.; Kwon, S.-K.; Kim, J.F. Genomics, Biological Features, and Biotechnological Applications of Escherichia coli B: Is B for better; Springer: Berlin, Germany, 2009.

3. Bilinski, P.; Kapka-Skrzypczak, L.; Posobkiewicz, M.; Bondaryk, M.; Holownia, P.; Wojtyla, A. Public health hazards in Poland posed by foodstuffs contaminated with E. coli O104:H4 bacterium from the recent European outbreak. Ann. Agric. Environ. Med. 2012, 19, 3-10.

4. Qadri, F.; Svennerholm, A.M.; Faruque, A.S.; Sack, R.B. Enterotoxigenic Escherichia coli in developing countries: Epidemiology, microbiology, clinical features, treatment, and prevention. Clin. Microbiol. Rev. 2005, 18, 465-483.

5. Al-Abri, S.S.; Beeching, N.J.; Nye, F.J. Traveller's diarrhoea. Lancet Infect. Dis. 2005, 5, 349-360.

6. Weintraub, A. Enteroaggregative Escherichia coli: Epidemiology, virulence and detection. J. Med. Microbiol. 2007, 56, 4-8.

7. Nataro, J.P.; Steiner, T.; Guerrant, R.L. Enteroaggregative Escherichia coli. Emerg. Infect. Dis. 1998, 4, 251-261.

8. Servin, A.L. Pathogenesis of Afa/Dr diffusely adhering Escherichia coli. Clin. Microbiol. Rev. 2005, 18, 264-292.

9. Darfeuille-Michaud, A. Adherent-invasive Escherichia coli: A putative new E. coli pathotype associated with Crohn's disease. Int. J. Med. Microbiol. 2002, 292, 185-193.

10. Negroni, A.; Costanzo, M.; Vitali, R.; Superti, F.; Bertuccini, L.; Tinari, A.; Minelli, F.; di Nardo, G.; Nuti, F.; Pierdomenico, M.; et al. Characterization of adherent-invasive Escherichia coli isolated from pediatric patients with inflammatory bowel disease. Inflamm. Bowel Dis. 2012, 18, 913-924.

11. Johnson, J.R.; Stell, A.L. Extended virulence genotypes of Escherichia coli strains from patients with urosepsis in relation to phylogeny and host compromise. J. Infect. Dis. 2000, 181, 261-272.

12. Gaschignard, J.; Levy, C.; Romain, O.; Cohen, R.; Bingen, E.; Aujard, Y.; Boileau, P. Neonatal bacterial meningitis: 444 cases in 7 years. Pediatr. Infect. Dis. J. 2011, 30, 212-217.

13. Pouillot, F.; Chomton, M.; Blois, H.; Courroux, C.; Noelig, J.; Bidet, P.; Bingen, E.; Bonacorsi, S. Efficacy of bacteriophage therapy in experimental sepsis and meningitis caused by a clone O25b:H4-ST131 Escherichia coli strain producing CTX-M-15. Antimicrob. Agents Chemother. 2012, 56, 3568-3575. 
14. Johnson, T.J.; Kariyawasam, S.; Wannemuehler, Y.; Mangiamele, P.; Johnson, S.J.; Doetkott, C.; Skyberg, J.A.; Lynne, A.M.; Johnson, J.R.; Nolan, L.K. The genome sequence of avian pathogenic Escherichia coli strain O1:K1:H7 shares strong similarities with human extraintestinal pathogenic E. coli genomes. J. Bacteriol. 2007, 189, 3228-3236.

15. Rodriguez-Siek, K.E.; Giddings, C.W.; Doetkott, C.; Johnson, T.J.; Fakhr, M.K.; Nolan, L.K. Comparison of Escherichia coli isolates implicated in human urinary tract infection and avian colibacillosis. Microbiology 2005, 151, 2097-2110.

16. Tivendale, K.A.; Logue, C.M.; Kariyawasam, S.; Jordan, D.; Hussein, A.; Li, G.; Wannemuehler, Y.; Nolan, L.K. Avian-pathogenic Escherichia coli strains are similar to neonatal meningitis E. coli strains and are able to cause meningitis in the rat model of human disease. Infect. Immun. 2010, 78, 3412-3419.

17. The Evolving Threat of Antimicrobial Resistance: Options for Action; World Health Organization: Geneva, Switzerland, 2012.

18. Von Baum, H.; Marre, R. Antimicrobial resistance of Escherichia coli and therapeutic implications. Int. J. Med. Microbiol. 2005, 295, 503-511.

19. Van der Bij, A.K.; Pitout, J.D. The role of international travel in the worldwide spread of multiresistant Enterobacteriaceae. J. Antimicrob. Chemother. 2012, 67, 2090-2100.

20. Szmolka, A.; Nagy, B. Multidrug resistant commensal Escherichia coli in animals and its impact for public health. Front. Microbiol. 2013, 4, 258, doi:10.3389/fmicb.2013.00258.

21. Magiorakos, A.P.; Srinivasan, A.; Carey, R.B.; Carmeli, Y.; Falagas, M.E.; Giske, C.G.; Harbarth, S.; Hindler, J.F.; Kahlmeter, G.; Olsson-Liljequist, B.; et al. Multidrug-resistant, extensively drug-resistant and pandrug-resistant bacteria: An international expert proposal for interim standard definitions for acquired resistance. Clin. Microbiol. Infect. 2012, 18, 268-281.

22. Johnson, T.J.; Nolan, L.K. Pathogenomics of the virulence plasmids of Escherichia coli. Microbiol. Mol. Biol. Rev. 2009, 73, 750-774.

23. Johnson, T.J.; Logue, C.M.; Johnson, J.R.; Kuskowski, M.A.; Sherwood, J.S.; Barnes, H.J.; DebRoy, C.; Wannemuehler, Y.M.; Obata-Yasuoka, M.; Spanjaard, L.; et al. Associations between multidrug resistance, plasmid content, and virulence potential among extraintestinal pathogenic and commensal Escherichia coli from humans and poultry. Foodborne Pathog. Dis. 2012, 9, 37-46.

24. Erb, A.; Sturmer, T.; Marre, R.; Brenner, H. Prevalence of antibiotic resistance in Escherichia coli: Overview of geographical, temporal, and methodological variations. Eur. J. Clin. Microbiol. Infect. Dis. 2007, 26, 83-90.

25. European Centre for Disease Prevention and Control. Antimicrobial Resistance Surveillance in Europe 2011; Annual Report of the European Antimicrobial Resistance Surveillance Network: Stockholm, Sweden, 2012.

26. Critically Important Antimicrobials for Human Medicine: Categorization for the Development of Risk Management Strategies to Contain Antimicrobial Resistance due to Non-Human Antimicrobial Use. In Proccedings of Report of the 2nd WHO Expert Meeting, Copenhagen, Danmark, 29-31 May 2007.

27. Poirel, L.; Bonnin, R.A.; Nordmann, P. Genetic support and diversity of acquired extended-spectrum beta-lactamases in Gram-negative rods. Infect. Genet. Evol. 2012, 12, 883-893. 
28. Canton, R.; Coque, T.M. The CTX-M beta-lactamase pandemic. Curr. Opin. Microbiol. 2006, 9 , $466-475$.

29. Livermore, D.M.; Canton, R.; Gniadkowski, M.; Nordmann, P.; Rossolini, G.M.; Arlet, G.; Ayala, J.; Coque, T.M.; Kern-Zdanowicz, I.; Luzzaro, F.; et al. CTX-M: Changing the face of ESBLs in Europe. J. Antimicrob. Chemother. 2007, 59, 165-174.

30. Lopez-Cerero, L.; Bellido, M.D.; Serrano, L.; Liro, J.; Cisneros, J.M.; Rodriguez-Bano, J.; Pascual, A. Escherichia coli O25b:H4/ST131 are prevalent in Spain and are often not associated with ESBL or quinolone resistance. Enferm. Infecc. Microbiol. Clin. 2013, 31, 385-388.

31. Rogers, B.A.; Sidjabat, H.E.; Paterson, D.L. Escherichia coli O25b-ST131: A pandemic, multiresistant, community-associated strain. J. Antimicrob. Chemother. 2011, 66, 1-14.

32. Walsh, F.; Rogers, T.R. Comparison of plasmid-mediated quinolone resistance and extended-spectrum beta-lactamases in third-generation cephalosporin-resistant Enterobacteriaceae from four Irish hospitals. J. Med. Microbiol. 2012, 61, 142-147.

33. Mugnaioli, C.; Luzzaro, F.; de Luca, F.; Brigante, G.; Perilli, M.; Amicosante, G.; Stefani, S.; Toniolo, A.; Rossolini, G.M. CTX-M-type extended-spectrum beta-lactamases in Italy: Molecular epidemiology of an emerging countrywide problem. Antimicrob. Agents Chemother. 2006, 50, 2700-2706.

34. Ewers, C.; Bethe, A.; Semmler, T.; Guenther, S.; Wieler, L.H. Extended-spectrum beta-lactamase-producing and AmpC-producing Escherichia coli from livestock and companion animals, and their putative impact on public health: A global perspective. Clin. Microbiol. Infect. 2012, 18, 646-655.

35. Queenan, A.M.; Bush, K. Carbapenemases: The versatile beta-lactamases. Clin. Microbiol. Rev. 2007, 20, 440-458.

36. Canton, R.; Akova, M.; Carmeli, Y.; Giske, C.G.; Glupczynski, Y.; Gniadkowski, M.; Livermore, D.M.; Miriagou, V.; Naas, T.; Rossolini, G.M.; et al. Rapid evolution and spread of carbapenemases among Enterobacteriaceae in Europe. Clin. Microbiol. Infect. 2012, 18, 413-431.

37. Shevchenko, O.V.; Mudrak, D.Y.; Skleenova, E.Y.; Kozyreva, V.K.; Ilina, E.N.; Ikryannikova, L.N.; Alexandrova, I.A.; Sidorenko, S.V.; Edelstein, M.V. First detection of VIM-4 metallo-beta-lactamase-producing Escherichia coli in Russia. Clin. Microbiol. Infect. 2012, 18, E214-E217.

38. Nordmann, P.; Naas, T.; Poirel, L. Global spread of Carbapenemase-producing Enterobacteriaceae. Emerg. Infect. Dis. 2011, 17, 1791-1798.

39. Mushtaq, S.; Irfan, S.; Sarma, J.B.; Doumith, M.; Pike, R.; Pitout, J.; Livermore, D.M.; Woodford, N. Phylogenetic diversity of Escherichia coli strains producing NDM-type carbapenemases. J. Antimicrob. Chemother. 2011, 66, 2002-2005.

40. Glasner, C.; Albiger, B.; Buist, G.; Tambic Andrasevic, A.; Canton, R.; Carmeli, Y.; Friedrich, A.; Giske, C.; Glupczynski, Y.; Gniadkowski, M.; et al. Carbapenemase-producing Enterobacteriaceae in Europe: A survey among national experts from 39 countries, February 2013. Euro Surveill. 2013, 18. Available online: http://www.eurosurveillance.org/View Article.aspx?ArticleId=20525 (accessed on 5 November 2013). 
41. Hopkins, K.L.; Davies, R.H.; Threlfall, E.J. Mechanisms of quinolone resistance in Escherichia coli and Salmonella: Recent developments. Int. J. Antimicrob. Agents 2005, 25, 358-373.

42. Hooper, D.C. Mechanisms of fluoroquinolone resistance. Drug Resist. Updats 1999, 2, 38-55.

43. Ruiz, J.; Pons, M.J.; Gomes, C. Transferable mechanisms of quinolone resistance. Int. J. Antimicrob. Agents 2012, 40, 196-203.

44. Robicsek, A.; Jacoby, G.A.; Hooper, D.C. The worldwide emergence of plasmid-mediated quinolone resistance. Lancet Infect. Dis. 2006, 6, 629-640.

45. Schito, G.C.; Naber, K.G.; Botto, H.; Palou, J.; Mazzei, T.; Gualco, L.; Marchese, A. The ARESC study: An international survey on the antimicrobial resistance of pathogens involved in uncomplicated urinary tract infections. Int. J. Antimicrob. Agents 2009, 34, 407-413.

46. Schultsz, C.; Geerlings, S. Plasmid-mediated resistance in Enterobacteriaceae: Changing landscape and implications for therapy. Drugs 2012, 72, 1-16.

47. Över, U.; Gur, D.; Ünal, S.; Miller, G.H.; Aminoglycoside Resistance Study Group. The changing nature of aminoglycoside resistance mechanisms and prevalence of newly recognized resistance mechanisms in Turkey. Clin. Microbiol. Infect. 2001, 7, 470-478.

48. Zarubica, T.; Baker, M.R.; Wright, H.T.; Rife, J.P. The aminoglycoside resistance methyltransferases from the ArmA/Rmt family operate late in the $30 \mathrm{~S}$ ribosomal biogenesis pathway. RNA 2011, 17, 346-355.

49. Lindemann, P.C.; Risberg, K.; Wiker, H.G.; Mylvaganam, H. Aminoglycoside resistance in clinical Escherichia coli and Klebsiella pneumoniae isolates from western Norway. APMIS 2012, $120,495-502$.

50. Livermore, D.M.; Mushtaq, S.; Warner, M.; Zhang, J.C.; Maharjan, S.; Doumith, M.; Woodford, N. Activity of aminoglycosides, including ACHN-490, against carbapenem-resistant Enterobacteriaceae isolates. J. Antimicrob. Chemother. 2011, 66, 48-53.

51. Galimand, M.; Sabtcheva, S.; Courvalin, P.; Lambert, T. Worldwide disseminated armA aminoglycoside resistance methylase gene is borne by composite transposon Tn1548. Antimicrob. Agents Chemother. 2005, 49, 2949-2953.

52. Van Duijn, P.J.; Dautzenberg, M.J.; Oostdijk, E.A. Recent trends in antibiotic resistance in European ICUs. Curr. Opin. Crit. Care 2011, 17, 658-665.

53. Kronvall, G. Antimicrobial resistance 1979-2009 at Karolinska hospital, Sweden: Normalized resistance interpretation during a 30-year follow-up on Staphylococcus aureus and Escherichia coli resistance development. APMIS 2010, 118, 621-639.

54. European Centre for Disease Prevention and Control. Annual Epidemiological Report 2012; Reporting on 2010 Surveillance Data and 2011 Epidemic Intelligence Data: Stockholm, Sweden, 2013.

55. Thorsteinsdottir, T.R.; Haraldsson, G.; Fridriksdottir, V.; Kristinsson, K.G.; Gunnarsson, E. Prevalence and genetic relatedness of antimicrobial-resistant Escherichia coli isolated from animals, foods and humans in Iceland. Zoonoses Public Health 2010, 57, 189-196.

56. Priamchuk, S.D.; Fursova, N.K.; Abaev, I.V.; Kovalev Iu, N.; Shishkova, N.A.; Pecherskikh, E.I.; Korobova, O.V.; Astashkin, E.I.; Pachkunov, D.M.; Kruglov, A.N.; et al. Genetic determinants of antibacterial resistance among nosocomial Escherichia coli, Klebsiella spp., and Enterobacter spp. isolates collected in Russia within 2003-2007. Antibiot. Khimioter. 2010, 55, 3-10. 
57. European Antimicrobial Resistance Surveillance System. EARSS Annual Report 2008; EARSS: Bilthoven, The Netherland, 2009.

58. Tonkic, M.; Goic-Barisic, I.; Punda-Polic, V. Prevalence and antimicrobial resistance of extended-spectrum beta-lactamases-producing Escherichia coli and Klebsiella pneumoniae strains isolated in a university hospital in Split, Croatia. Int. Microbiol. 2005, 8, 119-124.

59. Balode, A.; Punda-Polic, V.; Dowzicky, M.J. Antimicrobial susceptibility of gram-negative and gram-positive bacteria collected from countries in eastern Europe: Results from the Tigecycline Evaluation and Surveillance Trial (T.E.S.T.) 2004-2010. Int. J. Antimicrob. Agents 2013, 41, $527-535$.

60. Pitout, J.D. Multiresistant Enterobacteriaceae: New threat of an old problem. Expert Rev. Anti Infect. Ther. 2008, 6, 657-669.

61. Pitout, J.D. Extraintestinal pathogenic Escherichia coli: An update on antimicrobial resistance, laboratory diagnosis and treatment. Expert Rev. Anti Infect. Ther. 2012, 10, 1165-1176.

62. Paterson, D.L. Resistance in Gram-negative bacteria: Enterobacteriaceae. Am. J. Med. 2006, 119, S20-S28.

63. Kirchner, M.; Wearing, H.; Teale, C. Plasmid-mediated quinolone resistance gene detected in Escherichia coli from cattle. Vet. Microbiol. 2011, 148, 434-435.

64. Snow, L.C.; Warner, R.G.; Cheney, T.; Wearing, H.; Stokes, M.; Harris, K.; Teale, C.J.; Coldham, N.G. Risk factors associated with extended spectrum beta-lactamase Escherichia coli (CTX-M) on dairy farms in North West England and North Wales. Prev. Vet. Med. 2012, 106, $225-234$.

65. Platell, J.L.; Johnson, J.R.; Cobbold, R.N.; Trott, D.J. Multidrug-resistant extraintestinal pathogenic Escherichia coli of sequence type ST131 in animals and foods. Vet. Microbiol. 2011, 153, 99-108.

66. Hendriksen, R.S.; Mevius, D.J.; Schroeter, A.; Teale, C.; Jouy, E.; Butaye, P.; Franco, A.; Utinane, A.; Amado, A.; Moreno, M.; et al. Occurrence of antimicrobial resistance among bacterial pathogens and indicator bacteria in pigs in different European countries from year 2002-2004: The ARBAO-II study. Acta Vet. Scand. 2008, 50, 19.

67. Giufrè, M.; Graziani, C.; Accogli, M.; Luzzi, I.; Busani, L.; Cerquetti, M.; Escherichia coli Study Group. Escherichia coli of human and avian origin: Detection of clonal groups associated with fluoroquinolone and multidrug resistance in Italy. J. Antimicrob. Chemother. 2012, 67, 860-867.

68. Cengiz, M.; Buyukcangaz, E.; Arslan, E.; Mat, B.; Sahinturk, P.; Sonal, S.; Gocmen, H.; Sen, A. Molecular characterisation of quinolone resistance in Escherichia coli from animals in Turkey. Vet. Rec. 2012, 171, 151-154.

69. Aleisa, A.M.; Ashgan, M.H.; Alnasserallah, A.A.; Mahmoud, M.H.; Moussa, I.M. Molecular detection of $\beta$-lactamases and aminoglycoside resistance genes among Escherichia coli isolates recovered from medicinal plant. Afr. J. Microbiol. Res. 2013, 7, 2305-2310.

70. Gonzalez-Zorn, B.; Escudero, J.A. Ecology of antimicrobial resistance: Humans, animals, food and environment. Int. Microbiol. 2012, 15, 101-109.

71. Da Costa, P.M.; Loureiro, L.; Matos, A.J. Transfer of multidrug-resistant bacteria between intermingled ecological niches: The interface between humans, animals and the environment. Int. J. Environ. Res. Public Health 2013, 10, 278-294. 
72. Korzeniewska, E.; Korzeniewska, A.; Harnisz, M. Antibiotic resistant Escherichia coli in hospital and municipal sewage and their emission to the environment. Ecotoxicol. Environ. Saf. 2013, 91, 96-102.

73. Bedenic, B.; Vranes, J.; Hofmann-Thiel, S.; Tonkic, M.; Novak, A.; Bucevic-Popovic, V.; Hoffmann, H. Characterization of the extended-spectrum beta-lactamases and determination of the virulence factors of uropathogenic Escherichia coli strains isolated from children. Wien. Klin. Wochenschr. 2012, 124, 504-515.

74. Dedeic-Ljubovic, A.; Hukic, M.; Bekic, D.; Zvizdic, A. Frequency and distribution of diarrhoeagenic Escherichia coli strains isolated from pediatric patients with diarrhoea in Bosnia and Herzegovina. Bosn. J. Basic Med. Sci. 2009, 9, 148-155.

75. Coban, A.Y.; Nohut, O.K.; Tanriverdi Cayci, Y.; Bayramoglu, G.; Pirincciler, M.; Cetinkaya, E.; Cekic Cihan, C.; Bozdogan, B.; Durupinar, B. Investigation of plasmid-mediated quinolone resistance determinants in enterobacteriaceae: A multicenter study. Mikrobiyol. Bul. 2012, 46, 366-374.

76. Karch, H.; Denamur, E.; Dobrindt, U.; Finlay, B.B.; Hengge, R.; Johannes, L.; Ron, E.Z.; Tonjum, T.; Sansonetti, P.J.; Vicente, M. The enemy within us: Lessons from the 2011 European Escherichia coli O104:H4 outbreak. EMBO Mol. Med. 2012, 4, 841-848.

77. Marejkova, M.; Rohacova, H.; Reisingerova, M.; Petras, P. An imported case of bloody diarrhea in the Czech Republic caused by a hybrid enteroaggregative hemorrhagic Escherichia coli (EAHEC) O104:H4 strain associated with the large outbreak in Germany, May 2011. Folia Microbiol. 2012, 57, 85-89.

78. Bielaszewska, M.; Mellmann, A.; Bletz, S.; Zhang, W.; Kock, R.; Kossow, A.; Prager, R.; Fruth, A.; Orth-Holler, D.; Marejkova, M.; et al. Enterohemorrhagic Escherichia coli O26:H11/ $\mathrm{H}^{-}$: A new virulent clone emerges in Europe. Clin. Infect. Dis. 2013, 56, 1373-1381.

79. Markovska, R.; Schneider, I.; Ivanova, D.; Keuleyan, E.; Stoeva, T.; Sredkova, M.; Markova, B.; Bojkova, K.; Gergova, R.; Bauernfeind, A.; et al. High prevalence of CTX-M-15-producing O25b-ST131 Escherichia coli clone in Bulgarian hospitals. Microb. Drug Resist. 2012, 18, 390-395.

80. Boyer-Mariotte, S.; Duboc, P.; Bonacorsi, S.; Lemeland, J.F.; Bingen, E.; Pinquier, D. CTX-M-15-producing Escherichia coli in fatal neonatal meningitis: Failure of empirical chemotherapy. J. Antimicrob. Chemother. 2008, 62, 1472-1474.

81. Mielke, M. Prevention and control of nosocomial infections and resistance to antibiotics in Europe - Primum non-nocere: Elements of successful prevention and control of healthcare-associated infections. Int. J. Med. Microbiol. 2010, 300, 346-350.

82. Global Strategy for Containment of Antimicrobial Resistance; World Health Organization: Geneva, Switzerland, 2001.

83. Seib, K.L.; Zhao, X.; Rappuoli, R. Developing vaccines in the era of genomics: A decade of reverse vaccinology. Clin. Microbiol. Infect. 2012, 18, 109-116.

84. Gillings, M.R. Evolutionary consequences of antibiotic use for the resistome, mobilome and microbial pangenome. Front. Microbiol. 2013, 4, 4.

85. De Vrese, M.; Schrezenmeir, J. Probiotics, prebiotics, and synbiotics. Adv. Biochem. Eng. Biotechnol. 2008, 111, 1-66. 
86. Preidis, G.A.; Hill, C.; Guerrant, R.L.; Ramakrishna, B.S.; Tannock, G.W.; Versalovic, J. Probiotics, enteric and diarrheal diseases, and global health. Gastroenterology 2011, 140, 8-14.

87. Mennigen, R.; Bruewer, M. Effect of probiotics on intestinal barrier function. Ann. N. Y. Acad. Sci. 2009, 1165, 183-189.

88. Amdekar, S.; Singh, V.; Singh, D.D. Probiotic therapy: Immunomodulating approach toward urinary tract infection. Curr. Microbiol. 2011, 63, 484-490.

89. Tobias, J.; Svennerholm, A.M. Strategies to overexpress enterotoxigenic Escherichia coli (ETEC) colonization factors for the construction of oral whole-cell inactivated ETEC vaccine candidates. Appl. Microbiol. Biotechnol. 2012, 93, 2291-2300.

90. Isidean, S.D.; Riddle, M.S.; Savarino, S.J.; Porter, C.K. A systematic review of ETEC epidemiology focusing on colonization factor and toxin expression. Vaccine 2011, 29, 6167-6178.

91. Brumbaugh, A.R.; Mobley, H.L. Preventing urinary tract infection: Progress toward an effective Escherichia coli vaccine. Expert Rev. Vaccines 2012, 11, 663-676.

92. Moriel, D.G.; Bertoldi, I.; Spagnuolo, A.; Marchi, S.; Rosini, R.; Nesta, B.; Pastorello, I.; Corea, V.A.; Torricelli, G.; Cartocci, E.; et al. Identification of protective and broadly conserved vaccine antigens from the genome of extraintestinal pathogenic Escherichia coli. Proc. Natl. Acad. Sci. USA 2010, 107, 9072-9077.

93. Nikaido, H. Multidrug resistance in bacteria. Annu. Rev. Biochem. 2009, 78, 119-146.

94. Worthington, R.J.; Melander, C. Combination approaches to combat multidrug-resistant bacteria. Trends Biotechnol. 2013, 31, 177-184.

95. Haq, I.U.; Chaudhry, W.N.; Akhtar, M.N.; Andleeb, S.; Qadri, I. Bacteriophages and their implications on future biotechnology: A review. Virol. J. 2012, 9, 9.

96. Fjell, C.D.; Hiss, J.A.; Hancock, R.E.; Schneider, G. Designing antimicrobial peptides: Form follows function. Nat. Rev. Drug Discov. 2012, 11, 37-51.

97. Parisien, A.; Allain, B.; Zhang, J.; Mandeville, R.; Lan, C.Q. Novel alternatives to antibiotics: Bacteriophages, bacterial cell wall hydrolases, and antimicrobial peptides. J. Appl. Microbiol. 2008, 104, 1-13.

98. Kutateladze, M.; Adamia, R. Bacteriophages as potential new therapeutics to replace or supplement antibiotics. Trends Biotechnol. 2010, 28, 591-595.

99. Abedon, S.T.; Kuhl, S.J.; Blasdel, B.G.; Kutter, E.M. Phage treatment of human infections. Bacteriophage 2011, 1, 66-85.

100. Sulakvelidze, A.; Alavidze, Z.; Morris, J.G., Jr. Bacteriophage therapy. Antimicrob. Agents Chemother. 2001, 45, 649-659.

101. Brüssow, H. Phage therapy: The Escherichia coli experience. Microbiology 2005, 151, 2133-2140.

102. Maura, D.; Galtier, M.; Le Bouguenec, C.; Debarbieux, L. Virulent bacteriophages can target O104:H4 enteroaggregative Escherichia coli in the mouse intestine. Antimicrob. Agents Chemother. 2012, 56, 6235-6242.

103. Tsonos, J.; Adriaenssens, E.M.; Klumpp, J.; Hernalsteens, J.P.; Lavigne, R.; de Greve, H. Complete genome sequence of the novel Escherichia coli phage phAPEC8. J. Virol. 2012, 86, 13117-13118. 
104. Chibeu, A.; Lingohr, E.J.; Masson, L.; Manges, A.; Harel, J.; Ackermann, H.W.; Kropinski, A.M.; Boerlin, P. Bacteriophages with the ability to degrade uropathogenic Escherichia coli biofilms. Viruses 2012, 4, 471-487.

105. Sillankorva, S.M.; Oliveira, H.; Azeredo, J. Bacteriophages and their role in food safety. Int. J. Microbiol. 2012, 2012, 863945, doi: 10.1155/2012/863945.

106. Merabishvili, M.; de Vos, D.; Verbeken, G.; Kropinski, A.M.; Vandenheuvel, D.; Lavigne, R.; Wattiau, P.; Mast, J.; Ragimbeau, C.; Mossong, J.; et al. Selection and characterization of a candidate therapeutic bacteriophage that lyses the Escherichia coli O104:H4 strain from the 2011 outbreak in Germany. PLoS One 2012, 7, e52709, doi: 10.1371/journal.pone.0052709.

107. Doolittle, M.M.; Cooney, J.J.; Caldwell, D.E. Lytic infection of Escherichia coli biofilms by bacteriophage T4. Can. J. Microbiol. 1995, 41, 12-18.

108. Lacroix-Gueu, P.; Briandet, R.; Leveque-Fort, S.; Bellon-Fontaine, M.N.; Fontaine-Aupart, M.P. In situ measurements of viral particles diffusion inside mucoid biofilms. C. R. Biol. 2005, 328, 1065-1072.

109. Johnson, R.P.; Gyles, C.L.; Huff, W.E.; Ojha, S.; Huff, G.R.; Rath, N.C.; Donoghue, A.M. Bacteriophages for prophylaxis and therapy in cattle, poultry and pigs. Anim. Health Res. Rev. 2008, 9, 201-215.

110. Li, H.; Ma, M.L.; Xie, H.J.; Kong, J. Biosafety evaluation of bacteriophages for treatment of diarrhea due to intestinal pathogen Escherichia coli 3-2 infection of chickens. World J. Microbiol. Biotechnol. 2012, 28, 1-6.

111. Rangel, J.M.; Sparling, P.H.; Crowe, C.; Griffin, P.M.; Swerdlow, D.L. Epidemiology of Escherichia coli O157:H7 outbreaks, United States, 1982-2002. Emerg. Infect. Dis. 2005, 11, 603-609.

112. Niu, Y.D.; Stanford, K.; Kropinski, A.M.; Ackermann, H.W.; Johnson, R.P.; She, Y.M.; Ahmed, R.; Villegas, A.; McAllister, T.A. Genomic, proteomic and physiological characterization of a T5-like bacteriophage for control of Shiga toxin-producing Escherichia coli O157:H7. PLoS One 2012, 7, e34585, doi:10.1371/journal.pone.0034585.

113. Fischetti, V.A. Bacteriophage endolysins: A novel anti-infective to control Gram-positive pathogens. Int. J. Med. Microbiol. 2010, 300, 357-362.

114. Rodriguez-Rubio, L.; Martinez, B.; Donovan, D.M.; Rodriguez, A.; Garcia, P. Bacteriophage virion-associated peptidoglycan hydrolases: Potential new enzybiotics. Crit. Rev. Microbiol. 2013, 39, 427-434.

115. Hassan, M.; Kjos, M.; Nes, I.F.; Diep, D.B.; Lotfipour, F. Natural antimicrobial peptides from bacteria: Characteristics and potential applications to fight against antibiotic resistance. J. Appl. Microbiol. 2012, 113, 723-736.

116. Pande, J.; Szewczyk, M.M.; Grover, A.K. Phage display: Concept, innovations, applications and future. Biotechnol. Adv. 2010, 28, 849-858.

117. Lung, F.D.; Wang, K.S.; Liao, Z.J.; Hsu, S.K.; Song, F.Y.; Liou, C.C.; Wu, Y.S. Discovery of potent antimicrobial peptide analogs of Ixosin-B. Bioorg. Med. Chem. Lett. 2012, 22, 4185-4188. 
118. Pini, A.; Giuliani, A.; Falciani, C.; Runci, Y.; Ricci, C.; Lelli, B.; Malossi, M.; Neri, P.; Rossolini, G.M.; Bracci, L. Antimicrobial activity of novel dendrimeric peptides obtained by phage display selection and rational modification. Antimicrob. Agents Chemother. 2005, 49, 2665-2672.

119. Corrales-Garcia, L.; Ortiz, E.; Castaneda-Delgado, J.; Rivas-Santiago, B.; Corzo, G. Bacterial expression and antibiotic activities of recombinant variants of human beta-defensins on pathogenic bacteria and M. tuberculosis. Protein Expr. Purif. 2013, doi:10.1016/j.pep.2013.02.007.

120. Lira, F.; Perez, P.S.; Baranauskas, J.A.; Nozawa, S.R. Synthetic peptides antimicrobial activity prediction using decision tree model. Appl. Environ. Microbiol. 2013, 79, 3156-3159.

121. Tamma, P.D.; Cosgrove, S.E.; Maragakis, L.L. Combination therapy for treatment of infections with gram-negative bacteria. Clin. Microbiol. Rev. 2012, 25, 450-470.

122. Peleg, A.Y.; Hooper, D.C. Hospital-acquired infections due to gram-negative bacteria. N. Engl. J. Med. 2010, 362, 1804-1813.

123. Schweizer, H.P. Understanding efflux in Gram-negative bacteria: Opportunities for drug discovery. Expert Opin. Drug Discov. 2012, 7, 633-642.

124. Piddock, L.J.V. Multidrug-resistance efflux pumps-Not just for resistance. Nat. Rev. Microbiol. 2006, 4, 629-636.

125. Bioterrorism Agents/Diseases in Centers for Disease Control and Prrevention. Available online: www.bt.cdc.gov/agent/agentlist-category.asp (accessed on 5 October 2013).

126. Anderson, P.D.; Bokor, G. Bioterrorism: Pathogens as weapons. J. Pharm. Pract. 2012, 25, 521-529.

127. Masterton, R. The importance and future of antimicrobial surveillance studies. Clin. Infect. Dis. 2008, 47, S21-S31.

(C) 2013 by the authors; licensee MDPI, Basel, Switzerland. This article is an open access article distributed under the terms and conditions of the Creative Commons Attribution license (http://creativecommons.org/licenses/by/3.0/). 